\title{
University virtualisation in Latin America
}

\section{Claudio Rama}

University of Enterprise (UDE), Uruguay | claudiorama@gmail.com
Submitted in: December 2012

Accepted in: February 2014 Published in: July 2014

\section{Recommended citation}

Rama, C. (2014). University virtualisation in Latin America. RUSC. Universities and Knowledge Society Journal, 11(3). pp. 32-41. doi http://dx.doi. org/10.7238/rusc.v11i3.1729

\begin{abstract}
This article analyses the process by which higher education in Latin America is being digitalised, and how it is radically changing the educational dynamics in the region. The incorporation of digital technology implies a transformation of traditional distance education and the creation of new distance education dynamics. Indeed, some institutions are now offering fully online programmes, and there is a general increase in the digitalisation of face-to-face teaching. This study analyses the state of the art of the educational changes brought about by educational digitalisation in Latin America, and characterises the various aspects of it. It also describes the slow start in the region of a convergent education between the traditional distance and face-to-face modes.
\end{abstract}

\section{Keywords}

virtualisation; distance education; digital education; Latin America; reengineering

\section{La virtualización universitaria en América Latina}

\section{Resumen}

Este artículo analiza el proceso de digitalización de la enseñanza superior en la región, y estudia cómo está cambiando radicalmente la dinámica educativa en la zona. La incorporación de la tecnología digital implica un cambio de la educación a distancia tradicional, así como la creación de nuevas dinámicas en este campo, con instituciones que cuentan con programas cien por cien virtuales, y una creciente digitalización de la enseñanza presencial. Las próximas páginas analizan los cambios educativos que la digitalización educativa en América Latina y sus diversas vertientes han traído consigo. Estudian el lento inicio de una educación que hace converger las modalidades tradicionales, tanto presencial como a distancia.

\section{Palabras clave}

virtualización; educación a distancia; educación digital; América Latina; reingenierías 


\section{The expansion of distance education in Latin America and the impact of digitalisation}

The new paradigm arising from the incorporation of information and communication technologies (ICTs) into higher education, which manifests itself in virtual education, as an educational mode, is spreading very quickly throughout Latin America despite resistance that is clearly connected with traditional views of educational dynamics (Corica, 2012). However, such political and regulatory resistance is becoming weaker (Mena et al., 2007; Miklos, 2008; Lupion et al., 2010), and increasing levels of expansion have been noted in recent years (ABED, 2010).

Besides the pedagogical effectiveness of virtual education, it would appear that there are certain key dynamics behind this expansion, where the focus is on broader changes in productive structures resulting from the process of incorporating ICTs (Rosemberg, 2003). The Economic Commission for Latin America and the Caribbean (CEPAL, 2006) maintains that an economy is emerging in Latin America and the Caribbean, in which there is a proliferation of Internet-based digital networks and digital products.

Coverage differs, but it shows that the consolidation of certain private and public distance education institutions is now mature. These institutions are very large and have concentration levels that are far higher than the national averages. All of this is developing in a context of highly differentiated educational models that are articulated in accordance with the regulatory frameworks and university system characteristics of each particular country, as shown by a number of national studies (Observatorio de Virtual Educa). The private sector has grown considerably in recent years, also as a result of adopting this educational mode. In this setting, enrolments in the private distance education sector on a regional scale have been higher than those in the public sector, except in Costa Rica, Venezuela and Colombia, where part face-to-face, part distance public institutions created in the 1970s (National Distance University, UNA, Venezuela; State Distance University, UNED, Costa Rica, and National Open and Distance University, UNAD, Colombia) have prevailed in their respective local coverages (Rama, 2010b).

The public sector has not experienced any significant expansion under these modes because of multiple paradigm restrictions and a lack of any clear strategies on the issue in most of the region. The exceptions are Mexico and Brazil. In the first case, several virtual state universities and a national distance university have been created in the last five years. In the second case, and also in the last few years, an open public university has been created, which integrates the distance education offerings of public institutions and universities. In the rest of the region, there have not been any significant public initiatives related to this issue in the last decade.

In the first wave of distance higher education in the 1970s and 1980s, the public presence dominated (UNED, UNA and UNAD were archetypal cases), and all the offerings were local. In the current setting, however, there is a prevalence of private offerings, whose scant diversity and considerable size are striking.

\subsection{Distance education and new educational dynamics}

Albeit a minority mode at the current time, distance education is the most important driver of the increase in educational coverage in the region, with higher levels of growth than face-to-face, undergraduate and graduate education. At the same time, it is becoming more and more subject to minimum standards and systems of assessment and accreditation than traditional offerings. Although a difference in the types of student has been noted, a greater similarity with face-to-face modes in terms of the students' age, gender and graduation rates is emerging as its impact increases. This has been favoured by the widespread use of Moodle, which, being an open source virtual

RUSC VOL. 11 No 3 | Universitat Oberta de Catalunya and University of New England | Barcelona, July 2014 @ Claudio Rama | @ 2014 by FUOC | University virtualisation in Latin America 
leaning environment (VLE), is low-cost. Its highly versatile nature and negligible equipment requirements, and the minimal skills required to use it have made it very effective for the initially small scale operations of distance education. That has facilitated its rapid introduction, which is driving a significant reform. This impact is felt on enrolment, pedagogical practices, curricular structures, institutional functioning, educational internationalisation and professionals' offerings (Rama, 2012). This new technological and ultimately new cost structure setting facilitates new demands for access by higher income sectors and new suppliers, basically local. In the new context emerging from the technological change, greater public regulation and more pedagogical diversity have been found in the educational models of the whole region's distance education (UTPL, 2011; Rodríguez et al., 2010; Mena et al., 2007).

Driven by digital technologies, these dynamics of change have led to a boom in new distance higher education institutional offerings (blended learning), to the virtualisation of existing traditional part face-to-face, part distance education offerings resulting from institutional reengineering, and to the development of new, fully online educational models. Equally noteworthy is the incorporation of virtual teaching dynamics into face-to-face teaching, such as the increasing inclusion of practices and teaching dynamics in laboratories using information technology (IT) tools (AutoCAD or Excel spreadsheets, to name but a few), as well as various self-directed learning applications (for language learning, for example) and the virtualisation of administrative management.

\section{Reengineering of part face-to-face, part distance education institutions}

The path towards university distance education began in the late 1970s, when public institutions and programmes were created that could be accessed by means of part face-to-face, part distance education models. Unlike other parts of the world, the region lacked any significant historical experience of distance education in the university sector, or at any other level for that matter. From that time onwards, and with specific examples in some countries spurred on by the wave of expansion in demands for access and the setting of quotas in some face-to-face public institutions, distance education offerings began to take root in Colombia, Venezuela, Costa Rica and Mexico.

The new models emerging from these institutions did not include radio or television, apart from those in Brazil and Mexico, and generally a part face-to-face, part distance national model based on printed educational resources was rolled out. The model was expanded in those few countries via public institutions, thus enabling those students who were unable to attend higher education institutions to have access to educational programmes. The free public quotas limited by examinations and the high number of private enrolments were factors that fostered demand and its social stratification. These developments were the reverse side of the setting-up of quota systems and entrance tests at public universities.

\subsection{Educational technology and distance education}

With the advent of educational technologies based on microelectronics and computer programming (Mochi, 2005; Coriat, 2007), distance education underwent organisational reengineering to take advantage of the potential of technology (Bates, 2001; Rama, 2010). In the educational setting, that implied a switch from analogue to digital, from one-way to two-way communication, from low-frequency high-coverage signals (albeit limited to national borders given the type of transmission power permit and the height of the transmitter) to mechanisms and means of communication based on digital platforms and networks without any limitations on geographical coverage, 
and which ultimately tend to be international (Tiffin \& Rajasingham, 2007). The change also extended from models of asynchronous videoconferences via satellite or microwave or on CD or cassette, to distance classrooms via satellite or cable or Wi-Fi networks with synchronous educational interaction among the participants. This digital technology boom in the 1990s led to changes in the university offering market, with new local and international providers entering it, lower costs and more flexible offerings. The presence of the Monterrey Institute of Technology and Higher Education (TEC) in Latin America, or the National University of Distance Education (UNED) and the Open University of Catalonia (UOC) in Spain are proof of that, irrespective of the fact that it is not easy to get qualifications recognised because they often need to go through a process of assessing their equivalence.

In traditional distance universities (UNAD, Private Technical University of Loja (UTPL), UNA and ITESM), this manifested itself in the shift from first and second-generation technologies (the first being defined as those having flat, mainly graphic materials as the media, and the second as those having analogue radio and television as the media) towards educational dynamics based on third-generation technologies (those having VLEs and online digital resources as the media). In turn, that provided access to higher income social sectors, international resources and students, and an offering of new products and services (Chacón, 1994; Odorico, 2004). ICTs have also enabled a diversity in the dual-mode approach; no longer is it just traditional face-to-face or part face-to-face, part distance, but also blended or fully online, with or even without tutors, such as MOOCs (Daniel, 2012).

The reengineering undertaken to facilitate and drive the technological changes are not reforms within the same educational paradigm. They are processes that lead to improvements in quality, an increase in coverage and a reduction in direct costs, and also to opportunities and mobility for their users, educational resources that better reflect reality and greater interaction with other components. Consequently, better educational productivity is associated with an increase in the digitalisation of the various components, and these dynamics would appear to be leading towards educational automation.

Such changes are not taking place in every institution because, while the shift from a part face-to-face, part distance open model to a blended learning or fully online model may attract new students, it also runs the risk of excluding those students with fewer resources located in areas or homes with low levels of Internet access or financial resources that are more in keeping with the realities and characteristics of first-generation technologies. In many cases, this implies the non-relinquishment of the traditional part face-to-face, part distance educational model, and the superimposition of distance education technologies and models and a new dual-mode approach, with complex tensions, a struggle for resources and differences between groups, and levels of control and quality.

The transformation of distance higher education institutions resulting from the use of digital technologies involved an increase in total costs, thus running the risk of a potential loss of students from part face-to-face, part distance open modes. It also implied political and economic costs of dismantling the networks of face-to-face centres, initial and future technology infrastructure investment requirements, demands for higher competencies among administrative and teaching teams, and the digitalisation of their educational resources. Likewise, future virtualisation also imposes a constant renewal of equipment with a long-term change in the composition of spending on and investment in technological equipment and intellectual property rights (software and educational resources). This change in spending determines a modification in the contribution of capital and work in the end product, and its alteration shows that one factor replaces the other. In that sense, virtualisation as a process of incorporating technology can be inversely proportional to the participation of the teaching labour component in educational learning. Seen as a product, with a particular consumables structure, virtualisation replaces supervisory live work with dead work (pre-produced educational resources). This is the predominant aspect of MOOCs (Tapscott, 
2011; Bates, 2012). The rationale of incorporating educational resources is placing greater importance on those resources and less on the exclusive role of the teacher or lecturer. It constitutes yet another step in the process of incorporating the cultural or educational industries into teaching, along similar lines as the incorporation of the book. In institutions, the costs equation show that the proportional cost of teaching staff (salaries) is lower, and that the proportional cost of equipment, libraries and other educational resources is higher. The incorporation of digital educational technologies also drives administrative virtualisation, standardises management, simplifies procedures and reduces the cost of administrative processes.

With digitalisation from the late 1990s, changes slowly began to be introduced into pedagogical models, both face-to-face and part face-to-face, part distance (Montoya, 2004). Although relatively late on, new technologies facilitated both the restructuring and reengineering of traditional distance offerings. At that time, there was a shift from part face-to-face, part distance models to a blended learning model. In the region, this was corseted by the predominant regulatory frameworks that generally limited full virtualisation (Mena, 2006; Rama, 2010; UTPL, 2012)

Moodle was a real revolution that enabled distance education to be reengineered because, being an open source VLE, it had a low impact on costs in comparison to commercial VLEs like Blackboard, WebCT, FirstClass and others with high costs for small-scale operations. Thus, one of the aspects of university virtualisation in Latin America was slowly implemented within traditional distance education institutions: educational reengineering by introducing open source VLEs (mostly Moodle) that transformed their teaching model. Some institutions like UNED (Costa Rica) resolved a strategy of single-mode virtualisation for a while with several platforms, but finally concentrated on Moodle. In that institution, there was a total transition towards digitalisation, and the format went from part face-to-face, part distance to blended learning, incorporating VLEs, virtual tutors and digitalised educational resources. In others, given the resistance to change and the characteristics of the students and their environments, dual-mode dynamics were set up, providing students access to both modes, that is to say, part face-to-face, part distance, and blended learning.

In this context, the traditional distance education institutions that had historically characterised the Latin American landscape such as UNED (Costa Rica), UNA (Venezuela), UNAD (Colombia), the Open University SystemNational Autonomous University of Mexico (SUA-UNAM), UTPL (Ecuador), Norte de Paraná University (UNOPAR, Brazil) and TEC (Mexico), or those mass public universities typically offering open education such as the University of Buenos Aires (UBA, Argentina), the University of Panama and the National Autonomous University of Honduras (UNAH), have since moved towards blended learning models at different levels of intensity, or are in the process of doing so. Some of the institutions (UNAD) allowed their students to choose freely between the part face-to-face, part distance mode and the blended learning mode, and this enables us to note how enrolment on the blended learning mode has increased year on year, showing the shift in student demand under equal requirement conditions. In other cases, where a dual-mode system is in operation (part face-to-face, part distance, and online) (UNAH), it has been found that students choose the part face-to-face, part distance mode because it is less demanding and rigorous than the online mode or even the face-to-face mode.

The expansion of the blended learning mode, however, has not been greater because of the regulatory frameworks that impose the part face-to-face, part distance model, and because of limited Internet access or the type of students, even though these restrictions have very rapidly diminished as a consequence of the generalisation of access to the digital culture. Nevertheless, restrictions of a regulatory nature remain, and these impose face-toface activities. This limits the fully online offerings in most of the region's countries (Brazil, Argentina, Ecuador, Chile, Uruguay, etc.). In the majority of cases, face-to-face examinations or obligations to attend tutorials are imposed. A certain percentage may even be set for face-to-face activities (20\%, for example) (Mena, 2006; Lupion 2010; UTPL, 
2011). Some of the dual-mode (part face-to-face, part distance, and blended learning) cases analysed in Mexico (UNAM) and Colombia (UNAD) show a clear shift in demand and enrolment towards online supply.

\section{New fully online university education offerings}

In Latin America, there is a general lack of fully online university education, with the very recent exception of a few countries. This mode of teaching, which is fully mediated by digital environments, used to be employed mostly in the informal sector for unregulated continuing education qualifications. In the formal or regulated sector, offerings have recently been made available thanks to a relative relaxation of the traditionally restrictive public policies in Mexico, Colombia and Venezuela (for postgraduate only). These policies have begun to provide for fully online university offerings in both the private and public sectors. However, these provisions in the Official Recognition of Equivalence of Qualifications (RVOE) in Mexico and the Qualified Registry (Registro Calificado) in Colombia are very limited and minor. The use of VLEs, open educational resources (OERs), specific educational resources filmed by teachers or lecturers, interaction within virtual classrooms and the use of multiple choice assessment systems constitute the foundations of this educational model.

At the time of writing, there was a limited number of exclusively virtual universities, all of which had been recently set up, mostly in Mexico. There we find the Guadalajara Virtual University (an arm of the University of Guadalajara), the Guanajuato State Virtual University (public), the Veracruz State Clavijero Consortium (public), the Michoacán State Virtual University (public), the Online Mexican University (UMEL), TEC Virtual (with headquarters in Monterrey) and the Fray Luca Paccioli University (UFPL) (private).

They have also emerged in other countries in the region, albeit in a very limited way. They include the Catholic University of the North (private) in Colombia, Globalink Virtual University (private, only tertiary programmes have been authorised as yet) in Panama, and UNA and the Belloso Chacín University, with relatively few postgraduate programmes, in Venezuela. In many universities, there are units specially dedicated to virtual offerings. While they lack the ability to offer fully online university qualifications, they deal with online courses within university programmes, as well as extension or continuing education offerings. In Colombia, there are Qualified Registries (Registros Calificados) authorising fully online programme offerings in universities. They are teaching and learning processes without any face-to-face activities, in which teaching is mediated by a VLE.

\section{Virtualisation of face-to-face education}

Another trend in the virtualisation of higher education is the incorporation of IT tools into face-to-face education, meaning that the impact of fully online teaching processes is much higher than the simple coverage percentage of online or blended learning distance education. This is delivered by means of computer-based pedagogies, that is to say, teaching dynamics based on the use of applications in IT laboratories, access to educational resources on the Internet, computerised assessments of self-directed learning or doing practical activities for different subjects on computers. This is happening alongside other processes, such as enrolment, academic and administrative management, and the digital delivery of projects via VLES. The web-enablement of universities also shows a shift towards interactions that are more complex, focusing on learning and management alike. It is the external 
manifestation of virtual academic and administrative management dynamics internal to them, which constitutes a quality indicator. The global ranking highlights systematic progress of virtualisation and its association with the quality of teaching processes. 1 It is difficult to identify the increase in the amount of classes and moments during the teaching process that are being carried out in laboratories or on the students' personal computers (using any of the many self-directed learning or practical applications), but a clear upward trend can be observed, which is dependent on the development of open or closed source applications and each educational institution's own quality strategies. Although virtual education was initially conceived of as a new generation of distance education, in the context of an educational approach that differentiated between the two modes (face-to-face or online), an increasing diversity of digital environment situations can be found. It could be pictured as a process of transformation from dual mode to digital convergence, where, besides the predominance of the face-to-face or distance modes, there is room for a virtual rationale to develop in parallel to the process of digital convergence. In this respect, virtualisation restructures traditional face-to-face education by incorporating computer-based pedagogies in such a way that they then facilitate a learning-by-doing approach and better levels of retention and competency acquisition (Silva, 2012).

Computer-based pedagogies also facilitate the transition from linear learning to hypertext learning; from books as the only source of learning to multimedia resources; from non-interactive to interactive media; from micro libraries to the Internet; from passive learning to self-directed learning using software applications, thus changing the educational model that used to rely on didactic resources such as chalk, language and the blackboard. Computers are becoming a new educational instrument, in the same way as PowerPoint changed the dynamics of face-to-face classes and the Internet changed the way that information is accessed (Silvio, 2000). The increase in the number of computers per student, the academic interactions via VLEs or the existence of OERs are measures of that evolution and of the new realities. Computer-based pedagogy is becoming a competency-building mechanism (Araujo et al., 2008)

Education systems are shifting from an assessment of face-to-face practice to acquire learning, to the use of IT to acquire those competencies through systems of practice via VLEs. There is no doubt that computer-based pedagogy has its limitations. Nevertheless, some studies have shown that that the learning results obtained from it are better because it allows access to learning by doing, that is to say, not learning "from" a computer, but instead "with" a computer (Silva, 2012). It goes without saying that this is a process that depends on the disciplinary field, on the complexity of the IT tools and on the very development of technologies. In their evolution, these surpass the stimulus-response model, the simple concept of having access to information or of passive interaction, and enable advances to be made towards collaborative competency training tools with higher levels of interaction and representation of the reality of working environments. Self-directed learning software and simulation systems constitute tools that provide higher levels of learning.

Los sistemas educativos están pasando de la valorización de la práctica presencial, para alcanzar el aprendizaje, al uso de la informática para adquirir esas competencias a través de sistemas de prácticas en ambientes virtuales. Sin duda, la pedagogía informática tiene sus limitaciones, pero algunos estudios muestran que sus resultados en el aprendizaje son muy superiores por cuanto permiten ingresar a una educación haciendo, no a practicar «de» la computadora, sino «con» la computadora (Silva, 2012). Obviamente este es un proceso que depende de los campos disciplinarios y de la complejidad de las herramientas informáticas, así como del propio desarrollo de las tecnologías. En su evolución estas superan los modelos de estímulo respuesta, el simple concepto de acceso a la información,

1. See the criteria set and the rankings developed by these indicators at http://www.webometrics.info. 
o de interacción pasiva, para permitir evolucionar a herramientas de formación de competencias colaborativas con mayores niveles deinteraccióny representación delarealidad de los ámbitos del trabajo. El software deautoaprendizaje y los sistemas de simulación se constituyen en herramientas que proporcionan niveles superiores de aprendizaje.

\section{Conclusions}

Digital technologies are changing education, and various educational reforms have had to be made as a result. At the same time, these reforms are expanding digitally based distance education employing VLEs, online OERs and automated assessment. These dynamics have not only driven the reengineering of distance education institutions in Latin America, but they have also enabled the creation of fully online universities and teaching processes. In addition, they have led to a reconfiguration of the management of academic institutions and a transformation of face-to-face teaching with the ever-increasing incorporation ofteaching in laboratories, self-directed learning softwareapplications and distance education instruments such as VLEs, digital educational resources and automated assessment systems.

In general, however, a part face-to-face, part distance model has been maintained, though now in the form of blended learning as a consequence of adding digital educational resources, interaction via VLEs and the delivery of projects to assessments of face-to-face learning as a strategy to increase the quality of teaching processes in order to overcome the prevalence of low levels of interaction and the existence of flat educational resources. However, the use of videoconferences on Skype and multiple choice assessment systems is on the up because the latest versions of Moodle support them. Indeed, Moodle has become the most widely used VLE for the new digital classroom.

In this context, in 2010,10\% of Mexico's tertiary students were enrolled on fully online programmes, and 16\% of Brazil's new students were enrolled on distance programmes (ABED, 2010). Both modes, though fundamentally part face-to-face, part distance, with or without digital support, have grown from 1.3\% in 2000 to approximately $7.5 \%$ of all tertiary enrolments in Latin America, with 1.5 million students included in these educational modes (fully online; distance; part face-to-face, part distance; and blended learning) (IESALC, 2006; Rama, 2012).

Digital convergence between the traditional distance and face-to-face modes is manifesting itself in a reconfiguration of teaching that we could conceptualise as a new digital education. The incorporation of interaction, the opportunity to do practical activities in networked laboratories and the expansion of VLEs enable us to consider that we are witnessing the true beginnings of distance education, with the previous stages being reconceptualised as the 'prehistory' of this teaching mode, along a continuous path of including digital rationales and reducing the direct role of the teacher or lecturer, as today's MOOCs demonstrate.

\section{References}

Associaçao Brasileira de Educaçao a Distancia (ABED) (2010). CensoEAD.BR. Relatório analítico da Aprendizagem a distância no Brasil. São Paulo, Brazil: Pearson.

Araujo, U., \& Sastre, G. (Eds.) (2008). El aprendizaje basado en problemas. Una nueva perspectiva de la enseñanza en la universidad. Barcelona: Gedisa.

Bates, A. W. (2001). Cómo gestionar el cambio tecnológico. Estrategias para los responsables de centros universitarios. Barcelona: Gedisa.

RUSC VOL. 11 No 3 | Universitat Oberta de Catalunya and University of New England | Barcelona, July 2014 (a) Claudio Rama | @ 2014 by FUOC | University virtualisation in Latin America 
Bates, A. W. (2012). What's right and what's wrong about Coursera-style MOOCS? Retrieved from http://www.tonybates. ca/2012/08/05/whats-rigth-and-whats-wrong-about-coursera-style-moocs/

Chacón, F. (1994). Reingeniería de la educación abierta y a distancia en Latinoamérica. Caracas: Universidad Nacional Abierta. Retrieved from http://Ism.dei.uc.pt/ribie/docfiles/txt200352151352REINGENIER\%C3\%8DA\% 20DE\%20 LA\%20EDUCACI\%C3\%93N.pdf

Corica, J. L. (2012). Educación virtual y brecha digital de segundo nivel. In Morocho \& Rama (Eds.), Las nuevas fronteras de la educación a distancia. Loja: UTPL - Virtual Educa. Retrieved from http://www.virtualeduca.org/ documentos/observatorio/oevalc_2012_(fronteras).pdf

Coriat, Benjamin (2007). El taller y el robot. Ensayos sobre el fordismo y la producción en masa en la era de la electrónica. Mexico: Siglo XXI

Daniel, J.(1998). Mega-universities \& knowledgemedia.Technology strategiesforhighereducation. London:Kogan Page.

Daniel, J. (2012, April 13). Making Sense of MOOCs: Musings in a Maze of Myth, Paradox and Possibility. Retrieved from http://oregonhibbs.com/2012/12/22/on-moocs-by-sir-john-daniel/

LDB (Lei de Diretrizes e Bases da Educação Nacional. Brazil: Câmara dos Diputados. Retrieved from http://bd.camara. gov.br/bd/bitstream/handle/bdcamara/2762/ldb_5ed.pdf

Mena, M., Facundo, A., \& Rama, C. (2008). El Marco Regulatorio de la Educación Superior a Distancia en América Latina y el Caribe. Bogotá: ICDE, UNAD, Virtual Educa. Retrieved from http://www.virtualeduca.org/documentos/ observatorio/oevalc_2008_(marco.reg).pdf

Mochi, A., \& Prudencia, O. (2005). La producción de software, paradigma de la revolución tecnológica. In D. Crovi (Coord.), Sociedad de la información y el conocimiento (entre lo falazy lo posible). Buenos Aires: La Crujia Ediciones. Montoya Suárez, O. (2004), Schumpeter, innovación y determinismo tecnológico. Scientia et Technica 2(25). Bogotá: Universidad Tecnológica de Pereira.

Observatorio de Virtual Educa. Virtual Educa - OEA. Retrieved from http://www.virtualeduca.org/observatorio.htm

Odorico, A. (2004). Marco teórico para una robótica pedagógica. Revista Informática Educativa y Medios Audiovisuales 1(3), 34-46. Buenos Aires: Universidad de Buenos Aires.

Orozco Fuentes, B. (2009). Competencia y currículo: una relación tensa y compleja. Retrieved from http://www.riseu. unam.mx/documentos/acervo_documental/txtid0057.pdf

Pérez, C. (2004). Revoluciones tecnológicas y capital financiero. Mexico: Siglo XXI.

Pérez, C. (1996). Cambio técnico, restructuración competitiva y reforma institucional en los países en desarrollo. Santiago: CEPAL / CLADES.

Rama, C. (2012). La reforma de la virtualización de la universidad. El nacimiento de la educación digital. Guadalajara: Universidad de Guadalajara. Retrieved from http://www.virtualeduca.org/documentos/observatorio/libro_lareforma-de-la-virtualizacion-de-la-universidad-claudio-rama-udg-2012.pdf

Rama, C. (2010a). Las reingenierías de las instituciones de educación a distancia en América Latina. Santa Domingo: UNICARIBE

Rama, C. (2010b). La tendencia a la despresencialización de la educación superior. RIED 13(1). Retrieved from http:// www.biblioteca.org.ar/libros/141673.pdf

Rama, C. (2009). La encrucijada de las tendencias de la universidad latinoamericana. Montevideo: Universidad de la Empresa (UDE).

Rama, C., \& Domínguez Granda, J. (2010). El aseguramiento de la calidad en la educación virtual. Chimbote: ULADECH VirtualEduca.Retrievedfromhttp://www.virtualeduca.org/documentos/observatorio/oevalc_2011_(calidad).pdf 
Rosemberg, N. (2003). Ciencia innovación y crecimiento económico. In F. Chesnais \& J. C. Neffa (Comps.), Ciencia, tecnología y crecimiento económico. Buenos Aires: CEIL-PIETTE CONICET.

Silva Pontes, E. G. (2011). Tecnologías en el aprendizaje de la estadística (Unpublished doctoral thesis). Universidad de la Empresa, Montevideo, Uruguay.

Silvio, J. (2000). La virtualización de la universidad. ¿como podemos transformar la educación superior con la tecnología?

Caracas: IESALC

Tapscott, D., \& Williams, A. D. (2011). Macrowikinomics. Nuevas fórmulas para impulsar la economía mundial. Madrid:

Planeta.

Tiffin, J, \& Rajasingham, L. (2007). A universidade virtual e global. São Paulo: Artmed.

Universidad Técnica Particular de Loja (UTPL) (2011). Leyes, normas y reglamentos que regulan la Educación a Distancia y en línea en América Latina y el Caribe. Loja: UTPL.

\section{About the Author}

Claudio Rama

claudiorama@gmail.com, crama@ude.du.uy

Dean, Faculty of Business Sciences, University of Enterprise (UDE), Uruguay

He is a higher education researcher, lecturer and consultant. He holds a bachelor's degree in Economics (UCV), a master's degree in Education Management (UJMV), a doctorate in Education (UNESR), a doctorate in Law (UBA), and three postdoctoral qualifications (UNICAMP, UNESR, UFF). He is a member of the Uruguayan National System of Researchers $(\mathrm{SNI})$. He is the dean of the Faculty of Business Sciences, University of Enterprise (UDE), Uruguay. He is the director of the Virtual Educa Observatory of Virtual Education in Latin America. He was the director of the UNESCO International Institute for Higher Education in Latin America and the Caribbean (IESALC). In Uruguay, he was the director of the National Book Institute, director of the National Television System and vice-president of the Official Broadcasting and Entertainment Service (SODRE). He has given courses and lectures at more than 170 academic institutions and events in 30 countries, and has been a visiting academic for extended periods at UNAM and BUAP (Mexico) and UPR (Puerto Rico). He has published 21 books of his own, 10 books as a co-editor, 78 articles in books and peer-reviewed journals, and hundreds of articles in various newspapers. He was awarded the Uruguayan National Prize for Literature on two occasions for his academic writing, as well as three doctor honoris causa degrees (UNMSM, ULADECH, UIGV).

Universidad de la Empresa (UDE)

Soriano 959

Montevideo

Uruguay

Original title La virtualización universitaria en América Latina

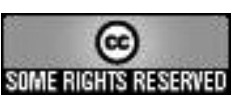

The texts published in this journal are - unless indicated otherwise - covered by the Creative Commons Spain Attribution 3.0 licence. You may copy, distribute, transmit and adapt the work, provided you attribute it (authorship, journal name, publisher) in the manner specified by the author(s) or licensor(s). The full text of the licence can be consulted here: <http://creativecommons.org/licenses/by/3.o/es/deed.en>

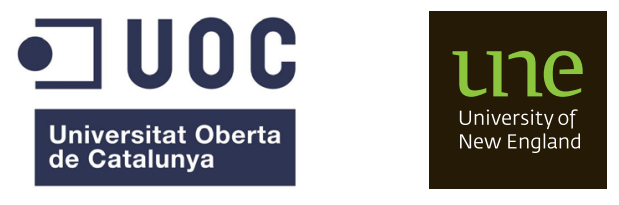

RUSC VOL. 11 No 3 | Universitat Oberta de Catalunya and University of New England | Barcelona, July 2014

@ Claudio Rama | @ 2014 by FUOC | University virtualisation in Latin America 